\title{
LDM (Life Detection Microscope): In situ Imaging of Living Cells on Surface of Mars
}

\author{
By Akihiko Yamagishi, ${ }^{1)}$ Takehiko SAtoH,${ }^{2)}$ Keigo EnYa, ${ }^{2)}$ Atsuo MiYaKawA, ${ }^{1)}$ Yoshitaka Yoshimura,,${ }^{3)}$ \\ Hajime HondA, ${ }^{4)}$ Eiichi IMAI, ${ }^{4)}$ Satoshi SASAKI, ${ }^{5)}$ Genya IsHigAmI, ${ }^{6)}$ Kazuhisa FuJita ${ }^{2)}$ and Hideaki MiYAMOTO ${ }^{7)}$ \\ 1) Tokyo University of Pharmacy and Life Sciences, Tokyo, Japan \\ 2) Japan Aerospace Exploration Agency, JAXA, Sagamihara, Japan \\ 3) Tamagawa University, Tokyo, Japan \\ ${ }^{4)}$ Nagaoka University of Technology, Nagaoka, Japan \\ 5) Tokyo University of Technology, Tokyo, Japan \\ ${ }^{6)}$ Keio University, Tokyo, Japan \\ 7) The University of Tokyo, Tokyo, Japan
}

(Received September 18th, 2015)

\begin{abstract}
Here we propose a new life detection project, to search for living microorganisms by fluorescence microscopy. We propose to search for "cells" from a depth of about $5-10 \mathrm{~cm}$ below the surface, which is feasible with current technology. Life Detection Microscope (LDM) that we propose here could detect less than $10^{4}$ cells in 1 gram clay. Our life-detecting instrument has the sensitivity that is orders of magnitude higher than the one onboard Viking that issued the negative conclusion. LDM is capable of identifying what we think to be the most fundamental features that a cell should possess to constitute life. Our Investigation Goals are: 1: High-resolution characterization of regolith and dust particles. 2: Search for any type of organic compounds in Mars surface samples. The compounds include cells, other biological materials, and abiotic polycyclic aromatic hydrocarbon (PAH). 3: Identify cell-like structure in which organic compounds are enveloped by membrane, which may represent Martian life. Among the planets and giant satellites in our solar system, the characteristics of Mars are most similar to those of Earth. This suggests that the life similar to terrestrial life may arise and survive on Mars.
\end{abstract}

Key Words: Mars, Fluorescence Microscope, Fluorescence Pigment, in situ Imaging, Living Cells

\section{Introduction}

Among the planets and giant satellites in our solar system, the characteristics of Mars, such as the size, mass, gravity, surface temperature, and the existence of an atmosphere are quite similar to those of Earth. This may suggest that it is possible for life similar to terrestrial life to arise and even survive on Mars.

The Viking missions in 1976, NASA's early landing missions to Mars, conducted several kinds of life science experiments. The Gas Exchange (GEX) Experiments measured production of gases from surface samples after they were humidified and wetted with nutrient media. In these experiments, the liberation of $\mathrm{O}_{2}$ gas was observed. ${ }^{1)}$ The Labeled Release (LR) Experiment demonstrated immediate evolution of radioactive gas after adding ${ }^{14} \mathrm{C}$-labeled carbohydrates to the Martian regolith. ${ }^{2}$ The Gas Chromatograph / Mass Spectrometer (GCMS) Experiment showed absence of detectable organic compounds above a few parts per billion in the upper $10 \mathrm{~cm}$ of surface soil. ${ }^{3)}$ The combined results of these experiments were interpreted to indicate the presence of oxidants that decomposed the organic compounds added in GEX and LR, and no organisms were present within the detection limits of the experiments. ${ }^{4)}$

However, the presence of life on Mars has become a focus of discussion again since the report of possible chemical fossils in the ALH84001 meteorite that originated from Mars. ${ }^{5)}$ The results of the Viking experiments have been reexamined. The Viking GCMS instruments were not specifically designed to search for living cells and the sensitivity for small organic compounds was one part per billion. Biomolecules such as amino acids could not be detected if living cells were present at levels less than $10^{7}$ cells per gram. ${ }^{6}$ Non-volatile organic compounds, such as benzenecarboxylate, which have been formed on the surface of Mars via oxidation of organic material that arrived on Mars in meteorites, could not be easily detected by the Viking GCMS instruments. ${ }^{7}$ Thus some organic compounds may be present on Mars, although compounds near the surface may be destroyed by ionizing radiation. ${ }^{8,9)}$

The evidence of past water activity and the existence of methane in the Martian atmosphere also provided motivation for the re-examination of the organic compounds on Mars surface. The Mars Global Surveyor (MGS) Mars Orbiter Camera (MOC) acquired images of the Martian surface with fine spatial resolution, and showed large outflow channels as evidence for past, but quite recent, liquid water. ${ }^{10-12)}$ The Mars Odyssey Neutron Spectrometer showed that poleward of $\pm 60^{\circ}$ latitude was terrain rich in hydrogen, probably $\mathrm{H}_{2} \mathrm{O}$ ice existing beneath tens of centimeters of soil. ${ }^{13)}$ Hydrated 
sulfate and phyllosilicates that provide evidence of the past presence of liquid water have been observed by the OMEGA imaging spectrometer on board the Mars Express spacecraft. ${ }^{14,15)}$ The Mars Exploration Rover Opportunity also found sedimentary rocks formed by past aqueous processes on Mars. ${ }^{16,17)}$ The Phoenix mission found a shallow $\mathrm{H}_{2} \mathrm{O}$ ice table in the center and edge of a nearby polygon at depths of 5 to 18 centimeters by excavating with the Robotic Arm and associated Icy Soil Acquisition Device. ${ }^{18)}$ These findings suggested that there was water activity on (or beneath) the surface and suitable conditions for life in the past, although there has been no direct observation of liquid water at present.

On the other hand, The Planetary Fourier Spectrometer onboard the Mars Express spacecraft detected methane at a concentration of approximately $10 \mathrm{ppbv}$ in global abundance. $^{19,20)}$ Similar abundance was observed by the Fourier Transform Spectrometer at the Canada-France-Hawaii Telescope. ${ }^{21)}$ Methane was released in large plumes and peak amounts were observed during Martian summer with high-dispersion infrared spectrometers. ${ }^{22}$ Methane is produced by both biotic and abiotic processes on Earth, so the origin of Martian methane is the subject of considerable discussion. ${ }^{23-26)}$ Mars Science Laboratory mission (MSL) has detected the temporally increase of the methane in the Gale Crater. $^{24)}$ The source may be revealed by the Mars Trace Gas Mission, which will spatially map important trace gases including methane using an orbiter. ${ }^{27)}$ The MSL will analyze not only the atmospheric composition, but also solids near the surface with a GCMS (gas chromatograph and quadrupole mass spectrometer) and a tunable laser spectrometer to measure organic compounds and isotope compositions, respectively and detected chlorinated methane, though the Martian origin is not clear yet. ${ }^{28)}$ The European Space Agency's ExoMars mission is planning life detection experiments on Mars with a Life Marker Chip, which detects biomolecules based on antibody microarray technology using subsurface samples taken by drilling or excavating. ${ }^{29)}$

Table 1. Current design of LDM.

\begin{tabular}{|l|c|}
\hline Volume (x, y, z) & $120 \times 160 \times 290 \mathrm{~mm}$ \\
\hline Weight & $6 \mathrm{~kg}$ \\
\hline Electricity & $20 \mathrm{~W}$ \\
\hline Wavelengths of laser diode & $488 \mathrm{~nm}(375 \mathrm{~nm}$ option $)$ \\
\hline Resolution & SYTO 24 and propidium iodide \\
\hline Dyes & From $-30^{\circ} \mathrm{C}$ to $30^{\circ} \mathrm{C}$ \\
\hline $\begin{array}{l}\text { Temperature range of dye } \\
\text { solution usage }\end{array}$ & From $-273^{\circ} \mathrm{C}$ to $50^{\circ} \mathrm{C}$ \\
\hline $\begin{array}{l}\text { Temperature range of dye } \\
\text { solution storage }\end{array}$ & \\
\hline
\end{tabular}

We propose a new life detection project on Mars to search for microorganisms by fluorescence microscopy. We propose to search for "cells" from a depth of about $5-10 \mathrm{~cm}$ below the surface, which is feasible with current technology. ${ }^{30)}$ Sampling devise is now being developed by one of our team members (G.I.) and will be published elsewhere. Microscopic observation can be done using low mass equipment with low electric power consumption (Table
1), and has the potential to detect single-form "cells". The terrestrial microorganisms often form aggregated cells usually called biofilm, which are easier to be detected. The single-form cell, usually with about $1 \mu \mathrm{m}$ in size, can be detected by LDM. The subsequent analysis of amino acids will provide the information needed to define the origin of the "cell", in the following mission.

\section{Survivability of Life in the Mars Environment}

Physical and chemical limits for terrestrial life have been major foci in astrobiology, ${ }^{31,32)}$ and are summarized in Table 1 in the previous publication. ${ }^{30}$ Microgravity may affect structural organization and functional harmonization of biological systems of higher organisms such as animals and plants (e.g., Refs. 31 and 33). In contrast, microorganisms are less affected by near-zero gravity. There is no evidence indicating that the low surface gravity of Mars $(0.376 \mathrm{~g})$ would limit the existence and survival of terrestrial life.

The temperature range for terrestrial life to grow is, from $-20^{\circ} \mathrm{C}$ to the current record of $122^{\circ} \mathrm{C},{ }^{34,35)}$ partially overlaps the temperature range of the current Mars surface, $-87^{\circ} \mathrm{C}$ to $20^{\circ} \mathrm{C}$. Besides growth, storage and survival of seeds, spores, vegetative cells and dried waterbears may not be significantly limited by the low Martian temperatures.

Although the terrestrial bacterium Shewanella oneidensis tolerates pressures as high as $1.6 \mathrm{GPa}^{36)}$ The effect of low pressures found on the current Mars surface against microorganisms has not been examined until recently. The terrestrial microorganism that can grow under the 0.007ATM atmosphere has been found. ${ }^{37)}$

Terrestrial life forms are found over the entire salinity range from freshwater to salt-saturated waters. Some halophilic (salt-loving) microorganisms such as Halomonas species maintain activity over the entire range of salinity (e.g., Refs. 38 and 39). It is likely that massive evaporation of liquid water occurred on Mars in the past, leaving massive evaporites that are salt-saturated. If $\mathrm{NaCl}$ is the major salt, many terrestrial halophilic microorganisms would be capable of survival. If Martian sea salts consist mainly of $\mathrm{Li}^{+}, \mathrm{K}^{+}, \mathrm{Ca}^{2+}$, and $\mathrm{SO}_{4}{ }^{2-}$, their possible influence on terrestrial-type life is not well defined. Associated with high salinity, the extreme dryness of the Mars surface is likely to limit biological activities, but not survivability, as evidenced by long-term storage of lyophilized (freeze-dried) microorganisms.

Radiation is likely the most seriously limiting factor for activity and survivability of terrestrial-type life; however, removal of water would increase tolerance and survivability. This hypothesis is based on the dried states of water bears, i.e., $\operatorname{tardigrades}^{40,33)}$ and chiromid larvae $e^{41,42)}$ as well as microorganisms. ${ }^{43}$ The extremely high radiation-tolerance of Deinococcus radiodurans has been well studied and ascribed to a by-product of adaptation to extreme desiccation. ${ }^{44)}$

UV radiation on the Mars surface can be estimated to be 20 $\mathrm{W} \mathrm{m}^{-2}$ based on the assumption that (1) UV radiation contributes about $10 \%$ of the Martian "solar constant" of $c a$. $600 \mathrm{~W} \mathrm{~m}^{-2}$, calculated from the Earth's solar constant of 1366 $\mathrm{W} \mathrm{m}{ }^{-2}$ and the Sun-Mars distance of $1.5 \mathrm{AU}$; and, (2) the thin 
Martian atmosphere cuts solar radiation by $c a .7 / 8$ (ca. 1/8 reaching the Mars surface). The Earth's atmosphere cuts radiation to $c a$. $1 / 500$, from a comparison of surface and space station altitudes; ${ }^{45,46)}$ and the Martian atmospheric pressure and surface gravity, 0.006 and 0.38 of the Earth's, respectively, would cut radiation to $c a$. $1 / 8$ (from $1 / 500 \div 0.006 \times 0.38$ ), which is a rough estimate of the Martian atmospheric shield performance. If the same shield performance holds for other ionizing radiations, $c a$. $1.2 \mathrm{mGy} \mathrm{day}^{-1}$ as determined during the 2001 Mars Odyssey mission on its orbit, a dose of 0.4 $\mathrm{mGy}$ day $^{-1}$ is estimated for the Mars surface.

The Phoenix Mars Lander performed ${ }^{47,48)}$ wet chemical analyses of the surface soil, and determined the soil $\mathrm{pH}$ to be $7.7 \pm 0.5$. For reference, the lowest (acidic) $\mathrm{pH}$ limit for terrestrial life is currently -0.06 , i.e., $\left[\mathrm{H}^{+}\right]=1.15 \mathrm{~mol} \mathrm{~L}^{-1}$, as shown by the archaea Picrophilus oshimae and $P$. torridus ${ }^{49,50)}$, while the highest (alkaline) pH12.5 is known for the bacterium Alkaliphilus transvaalensis. ${ }^{51)}$

The redox potential $\left(\mathrm{E}_{\mathrm{h}}\right)$ of the Martian soil has not been reported so far, but occurrences of sulfate and perchlorate strongly suggest that the Martian soil is highly oxidative and coincides with the presence of ferric oxides on the surface. Perchlorate, an efficient oxidizer, is present in the Martian soil, but may not restrict the survivability of life on Mars, since certain terrestrial microorganisms exploit perchlorate in anaerobic oxidation metabolism. ${ }^{52,53)}$

Results of the Viking biological experiments were interpreted to indicate the presence of highly oxidizing $\mathrm{H}_{2} \mathrm{O}_{2}$, which could be generated by photochemical reactions and/or dust storms. ${ }^{54)}$ Many microorganisms show high tolerance to $\mathrm{H}_{2} \mathrm{O}_{2}$, and thus any possible Martian life may not be damaged too seriously by $\mathrm{H}_{2} \mathrm{O}_{2}{ }^{55)}$ Oxidation by superoxide ions $\left(\mathrm{O}^{2-}\right)$ in the Mars soil has also been proposed, ${ }^{56)}$ and many terrestrial organisms possess the enzyme superoxide dismutase to catalyze transformation of $\mathrm{O}^{2-}$ to $\mathrm{O}_{2}$ and $\mathrm{H}_{2} \mathrm{O}_{2}$. Therefore, survivability of Martian life may not be heavily damaged by $\mathrm{O}^{2-}$.

\section{How to Find Microorganisms on Mars}

The Martian soil will be inspected with a fluorescence microscope. Using a combination of fluorescent dyes, specific components of biological cells can be distinguished from non-biological inorganic and organic matters. Adequate combination of pigments used will be determined to detect biological characteristics.

The component and the shape of the possible Martian life is not known, if ever emerged. However, based on the environmental similarity between early Earth and early Mars, we assumed the similarity between life-forms emerged on these two planets. The organic compounds were found in space, meteorite and comet and must accumulated on Mars as well as Earth. The life forms on Mars must utilize organic compounds as biological polymers. The first target of our LDM observation is the organic compound.

All the terrestrial life consists of a cell(s), which are surrounded by lipid membrane. The cells maintain concentration of biological compounds in cells by membrane.
The Martian "cell" must be surrounded by membrane. The "cell" should be surrounded by an impermeable membrane to define "self" and "non-self" and to separate inside from outside. The presence of this defining characteristic will be tested by using a combination of membrane permeable (SYTO 24) and impermeable (propidium iodide) pigments.

Upon identification of candidate "cells" by fluorescence microscopy, they will be analyzed by second stage analytical process, in the next separate mission. In the second stage, the "cells" will be hydrolyzed with solid-acid catalyst, and the amino acids will be derivatized and analyzed with GC-MS.

Living cells on Earth consist of $70 \%$ water and $15 \%$ protein. Cells contain many types of proteins, from as many as several thousand proteins in prokaryotes, to several tens of thousands in eukaryotes, each having a molecular weight from a few thousand to several hundred thousand. The molecular weight spectra are too complex to be resolved by any type of mass spectral detectors. However, once proteins are hydrolyzed, they produce a mixture of 19 chiral-specific amino acids and glycine, which has no optical isomer. A specific set of 20 amino acids is commonly found in all cells on Earth. Based on research on chemical evolution, which must have occurred prior to the emergence of life, amino acids are known to be abiotically produced in a wide range of possible pre-biological environments. Accordingly, there is a fair chance that Martian "cells" contain polymers of amino acids. However, the number, types and chirality of the amino acids may not be the same as those in living cells on Earth. The number and characteristics of amino acids will be analyzed in the second stage of "cell" analysis.

\section{Fluorescent Microscopy}

Fluorescent microscopy is a method to detect localized biosignatures in situ. Biosignatures are labeled with fluorescent dyes. Stained objects are observed with an epifluorescence microscope with a resolution of $1.0 \mu \mathrm{m}$. Because the fluorescent cell can be detected in the dark back ground in fluorescent microscopy, $1 \mu \mathrm{m}$ resolution is sufficient to detect any fluorescent object as small as $0.2 \mu \mathrm{m}$, the size of virus. This method is as highly sensitive as about $10^{4}$ cells per g-soil can be detected and will provide clear evidence for extraterrestrial life as images. Many fluorescent dyes are commercially available and used routinely to study terrestrial microorganisms. ${ }^{57,58)}$ Thus, their validities have been well established. Analytical procedures are simple and can be done in a short time. Weinstein et al. (2008) ${ }^{59)}$ tested a detection instrument, Fluorescence Imager, in the Atacama desert in Chile. They sprayed several $\mathrm{mL}$ of dye solutions on soil and rocks, and detected a variety of visible life forms such as lichens with CCD camera with fiber optics, although their system was limited to detect life larger than $1 \mathrm{~mm}$. We have developed the window-bottom sample holder which enables the usage of a high resolution objective lens as described in section 5, instead of using fiber optics.

To apply this method to detect Martian microorganisms, we have designed a strategy to detect "cells". Our method is based on multilabeling with different types of fluorescent dyes. 
The principle is to detect biosignatures that are responsible for the basic characteristics of life: organic compound, and discrimination of self from non-self. ${ }^{60)}$ Each characteristic will be detected using a different type of fluorescent dye that is specific for organic compounds but the different permeability to the membrane. This combination of dyes has a potential to distinguish living "cells" from dead "cells" and other non-biological organic compounds.

Nucleic acid probes are most commonly used to study microbial ecology. AO (acridine orange), DAPI (4',6-diamidino-2-phenylindole), SYBR Green I and II, and SYBR Gold are examples of this type of probe. ${ }^{61-64)}$ Although many probes cannot be used on soil samples because of strong binding to mineral particles, some probes such as AO were reported to be useful for endolith samples. ${ }^{65)}$

Metabolic activities are detected by using enzyme substrate fluorescent dyes. FDA (fluorescein diacetate), CFDA (5-carboxyfluorescein diacetate), SFDA (5-(and 6-) sulfofluorescein diacetate), and CFDA-AM (5-carboxyfluorescein diacetate, acetoxymethyl ester) have been used for this purpose. ${ }^{66-71)}$ These dyes are often used as viability indicators. They remain non-fluorescent unless hydrolyzed by the intracellular enzyme, esterase, which is a ubiquitous enzyme in organisms on earth. In the case of soil, this type of dye often shows intense background fluorescence due to abiotic catalytic activities and leakage of fluorescent product from the cells, which can mask stained microorganisms. SFDA used with ethanol can solve this problem. ${ }^{70)}$ Some dyes were also reported to detect artificial protenoid microspheres, which could have enzymatic activity. ${ }^{60)}$ Accordingly, this type of dye has the potential to detect enzyme-like catalysts. If living microorganisms are present on Mars, they could be detected with this type of probe, because microorganisms must possess catalytic activities to maintain their metabolism.

Cell membranes surrounding "cells" may be identified by using a combination of cell-membrane permeable and impermeable nucleotide specific dyes such as LIVE/DEAD BacLight. ${ }^{77)}$ However, nucleotides may or may not be the genetic components of possible Martian "cells", thus a combination of pigments with broad staining specificities for not only nucleotide but also protein or protenous molecules will be used to search for candidate "cells" surrounded by membranes.

In addition, fluorescent dyes that detect protein or amino acids could be useful to search for pre-biotic organic materials. SYPRO-RED, ${ }^{78)}$ fluorescamine ${ }^{80}$ and other amine reactive dyes that react specifically with amino groups ${ }^{57)}$ are candidates for this type of probe.

Many fluorescent probes were extensively studied by Nadeau et al. (2008). ${ }^{65)}$ They showed that the usefulness of a particular fluorophore strongly depended on the particular sample and means of detection, and that all fluorescent pigments showed some nonspecific binding. We have selected fluorescent dyes and staining methods that minimize nonspecific binding using simulated Martian samples. Multilabeling with different types of dyes will be tested to increase the detection accuracies and to decrease the identification of false positive (abiotic) structures.
We have found that SYTO 24 and propidium iodide suite best for staining organic compounds not only nucleotides. The combination of pigments is able to stain not only nucleic acids but also wide range of organic compounds including protein, proteinoid and polycyclic aromatic hydrocarbon. There is a mutant Escherichia coli produces daughter cells without DNA that is called mini-cell, while DNA is retained in mother cell. The mini-cells were stained green when they are alive and stained red when they are dead, with the combination of the pigment SYTO 24 and propidium iodide.

These two pigments, SYTO 24 and propidium iodide, are able to detect cells of microorganism in soils of natural environments such as of Antarctic desert and Atacama Desert. Low density microbial cells $\left(10^{4}\right.$ cells/gram soil $)$, in simulated Martian regolith (JSC-Mars-1) containing perchlorate, were detected with $18 \%$ and $5 \%$ efficiency, by SYTO 24 and propidium iodide, respectively.

The stabilities of these two pigments, SYTO 24 and propidium iodide, against space and Martian environmental factors were also tested. No decrease in efficiency in staining microbial cells were detected after the 80 Gy gamma radiation on these two pigments, which are expected during the cruise to Mars and expected 60-sol lover expedition, though the dose during the surface of Mars is much less than those during the cruise. These pigments retain sufficient ability to stain cells after the 50 sols of the temperature cycle with the peak temperature $50{ }^{\circ} \mathrm{C}$.

High-resolution images with a micron scale will also provide information about the morphology of the candidate "cells". Terrestrial microorganisms often have specific morphological characteristics, such as spherical and rod shapes, and a characteristic size distribution. Size is usually defined within a range of a single species or group of similar species. Together with the fluorescence intensity from the combination of different fluorescence probes and the morphological information, we will be able to define the characteristics of the candidate "cells".

\section{Development of Fluorescence Microscope}

The scientific target of this instrument is to search for life form, 'cell', on the surface of Mars. To identify 'cell' we have selected a pair of fluorescence pigments specific to wide variety of organic compounds, one with high permeability and the other with low permeability to the membrane. With the combination of the two fluorescence pigments, it is possible to detect the organic compounds surrounded by membrane, which is most likely representing 'cell'. The size of terrestrial microbiological cell varies from 0.2 to tens of $\mu \mathrm{m}$ in length. However, the species with smallest sizes are the heterotrophic parasitic species. The cell sizes of free living species are larger than $0.5 \mu \mathrm{m}$, which can be detected by the $1 \mu \mathrm{m} /$ pixel imaging resolution from the dark background. The lowest density of microbiological cell is reported from the desert soil of Atacama, which is $10^{4}$ cells/gram soil. The microscope is designed to detect the lowest possible microbiological density expected. To search for possible cell on the surface of Mars, we are to search the places with the highest possibility in 
detecting Martian microorganisms. Though the target place is discussed in the next section, to increase the possibility of detecting cells, multiple samples should be analyzed.

The microscopic instrument which is to be used on Mars should suffice the requirement: a) To analyze multiple samples, b) To detect the organic particle with the sensitivity $10^{4}$ particles/gram sample, c) To distinguish pigment fluorescence from those from mineral particles, d) To distinguish organic compounds surrounded by membrane from other organic compounds.

To fulfill the requirement the instrument should: a) have multiple sample holders, b) take image to detect particles statistically suffice the sensitivity, c-1) add pigment solution(s), c-2) take images with two different fluorescence band (green and red), d) have the image resolution of $1 \mu \mathrm{m}$.

To achieve the sensitivity $10^{4}$ particles/gram sample, $2 \mathrm{~mm}^{3}$ are going to be inspected and 20 particles will be detected. Based on the efficiency in detecting microorganism 4 and 1 particles will be detected by SYTO 24 and propidium iodide, respectively.

To achieve the $1 \mu \mathrm{m}$ resolution, we have developed the sample holder with window bottom. The sample can be inspected from the bottom window with a biological microscopic objective lens. We have preliminary design of objective lens with seven to nine combination lenses, and found it possible to design optical lens with sufficient optical performance. To observe the $2 \mathrm{~mm}^{3} 200$ fields have to be observed with $1 \mathrm{~mm} \times 1 \mathrm{~mm}$ field and $10 \mu \mathrm{m}$ focus depth, which can be achieved by scanning 20 field-scan for $X$ and/or $\mathrm{Y}$ directions and 10 scans for $\mathrm{Z}$ direction. We have made a principle test model of $\mathrm{X}$ - scans, as well as changing the sample holder with the bottom grass window equipped with automated airtight lid open and close upon necessity.

In addition to above requirement, physical condition of the pigment solution has to be considered. Under the Martian atmospheric pressure, liquid water is quickly evaporated or frozen under low temperature. To decrease the two possibilities we found $67.7 \%$ glycerol solution are adequate solvent for fluorescent pigment. The freezing point of $67.7 \%$ glycerol solution is $-46.5^{\circ} \mathrm{C}$. The solution can maintain liquid state for more than 200 min under the Martian pressure $7 \mathrm{hPa}$ with a small hole $(0.15 \mathrm{~mm}$ diameter $)$, and the retaining $71 \%$ glycerol have the freezing point $-33^{\circ} \mathrm{C}$. Glycerol is often used in microbiology as antifreeze additives and has little effect on terrestrial microorganisms. We have tested the ability to use the $67.7 \%$ glycerol to stain microbial cells with fluorescence pigment as shown in the previous section. With the $67.7 \%$ glycerol solution instrument is operational between $-30^{\circ} \mathrm{C}$ and $+30^{\circ} \mathrm{C}$ under the Martian atmosphere.

The sufficient volume of dye solution $(2 \mathrm{ml})$ for each sample analysis is stored in a dye-storage between thin metal films for each sample. The metal films will be punctured by the needle safe-locked below the dye-storage during the voyage to and traveling on the surface of Mars.

To save electricity, a laser diode (LD) will be used to excite dye-labeled samples. The laser diodes of wavelengths such as $375 \mathrm{~nm}$ or $488 \mathrm{~nm}$ for different types of fluorescent dyes will be equipped. We have tested and detected no deterioration of
LD after 80 Gy gamma irradiation and after temperature cycle of -40 and $50^{\circ} \mathrm{C}$. To detect the low fluorescence emitted by the $10 \mathrm{~mW}$ optical output power LD, we will select adequate CCD with high sensitivity, suffice the $1 \mu \mathrm{m}$ resolution.

\section{Where to Search: Location of Liquid Water}

As discussed in section 1, there are series of reasons to believe that ancient Mars have had environment somewhat similar to that of Earth. Those include the existence of large bodies of water, a wide range of surface oxidation states, appearances of variety of chemical components potentially building blocks of life, and evidence of ancient magnetic field. Endogenic activities have continued even until very recently, and recent water-related geological features indicate prolonged existence of an aquifer system, where a habitable environment may exist for a significant period of time. Occasional releases of volatiles from such an aquifer system may ultimately account for the inconclusive result (not unambiguous denial) of metabolism-detection instrument onboard Viking landers.

The Life Detection Microscope (LDM) instrument experiment is designed to detect less than $10^{4}$ cells in 1 gram clay, more than hundred-times higher than previous attempts performed by Viking landers. There might be decent chances of microorganisms still existing subsurface or somewhere shallow at depth, and if so, they may migrate all over Mars as results of such as global dust storms and repetitious impacts of small meteoroids. In this sense, we consider that, if we can perform this instrument almost anywhere on Mars, it would be an extremely variable experiment.

Even though we consider the LDM has sufficient capability of evaluating if life exists on anywhere on Mars, if we try to maximize the chances of finding microorganisms, it would simply depends on the landing-site. Its selection may be based on the possibility of the existence of near-surface water and on recent geological and hydrological activities including the possible release of volatiles. More specifically, we propose locations satisfying the following conditions has highest chances of finding microorganisms on the surface of Mars; (1) a region with a relatively high water activity $(\mathrm{Aw}>0.6),(2) \mathrm{a}$ region with a relatively higher maximum environmental temperature ( $\mathrm{T}>250)$, and (3) an existence of gradients of free energy.

Among the currently-developing features on Mars, seasonal flows on slopes (recurring slope lineae, RSL) are considered the most important features because they are most likely related to water activity. Liquid brine near the surface is considered to be the best explanation for such activity because (1) Incremental growths are observed during warm seasons at temperature higher than 250K; (2) They appear only on warm slopes (McEwen et al., 2011 and 2014); ${ }^{75,76)}$ (3) Strength of absorptions at 539 and $920 \mathrm{~nm}$ varies seasonally (Ojha et al., 2014). ${ }^{77)}$ Most RSL are found in southern hemisphere, but some other exceptions exist such as in Valles Marineris. Given the above view, we propose Melas chasma as a prime candidate because of the existence of "confirmed" recurring slope lineae, where incremental growth of RSLs have been 
observed. The reasons also include the fact that Valles Marineris provides the best exposures of the ancient geologic history of Mars: (1) being the widest and deepest part of the Valles Marineris and thus a major catchment basin of Mars since its formation; (2) being connected to the outflow channels; (3) possible fog for at least part of a Martian day; (4) containing Interior Layered Deposits (ILDs) which comprise various sulfates deposits, as well as phyllosillicates among the canyon units, both of which are suggestive of abundant past water; (5) comprising a volcanic field in its southeast part; and (6) being cut by deep-seated basement structures that served as conduits for the migration of both groundwater and heat.

As another line of consideration, we propose to look at the locations with the current volatile release. We find Tharsis/Elysium Corridor region is the best candidate, which shows evidence of long-lived water enrichment and recent geologic activity, including recent venting that could bring materials from the subsurface to the surface environment.

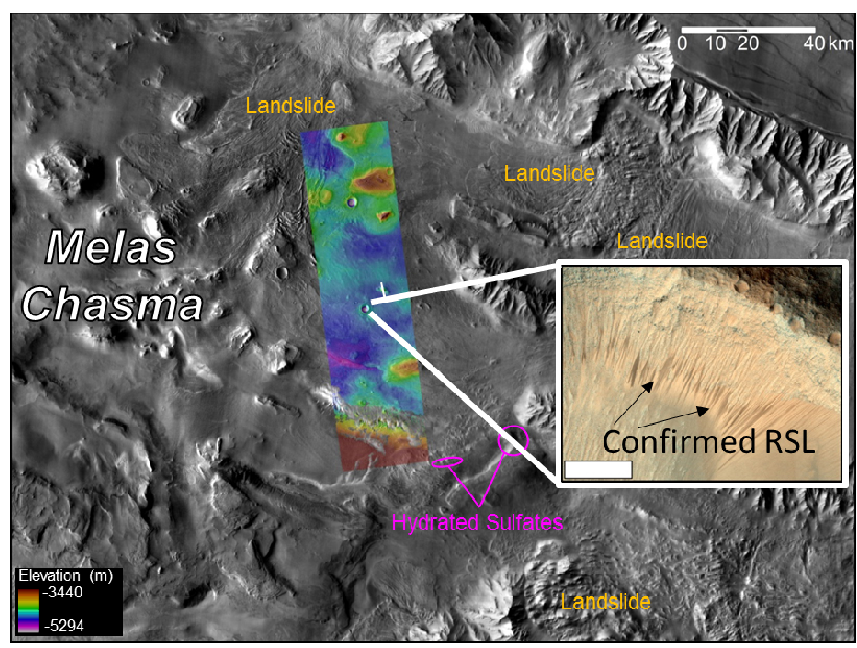

Fig. 1. Melas chasma inside Valles Marineris. We propose $68.52 \mathrm{~W}$ $11.47 \mathrm{~S}$ as a prime landing-site for the LDM (the center of this image). Confirmed RSL are found on a crater wall of this region. Relatively flat surface conditions and elevation $(-4.8 \mathrm{~km}$ from the Mars average) provide engineering advantages for a safer landing.

\section{Conclusions}

In conclusion, we propose to search for microorganisms on Mars, 5 to $10 \mathrm{~cm}$ below the surface. A combination of fluorescent dyes will be used to detect candidate "cells" using a fluorescence microscope. Putative "cells" will be hydrolyzed and analyzed by mass spectral analysis to define the characteristics of the candidate "cells" in the following mission, which will indicate the origin of the candidate. Melas chasma inside Valles Marineris is proposed as a candidate site for the landing and LDM exploration, because there are seasonal flows on slopes (recurring slope linear, RSL) that are considered the most important features because they are most likely related to water activity.

\section{Note Added in Proof}

The organic compound of Mars origin was detected from the mudstone corrected a few $\mathrm{cm}$ below surface in Gale Crater on Mars by Sample Analysis on Mars onboard MSL: Curiosity. $^{78)}$

\section{Acknowledgments}

The research was supported in part by ISAS/JAXA fund for MELOS waking group and LDM working group.

\section{References}

1) Oyama, V. I. and Berdahl, B. J.: The Viking Gas Exchange Experiment Results From Chryse and Utopia Surface Samples, J. Geophys. Res., 82, 28 (1977), pp.4669-4676.

2) Levin, G. V. and Straat, P. A.: Recent Results from the Viking Labeled Release Experiment on Mars, J. Geophys. Res., 82, 28(1977), pp.4663-4667.

3) Biemann, K., Oro, J., Toulmin, P., III, Orgel, L. E., Nier, A. O., Anderson, D. M., Simmonds, P. G., Flory, D., Diaz, A. V., Rushneck, D. R., Biller, J. E. and Lafleur, A. L.: The Search for Organic Substances and Inorganic Volatile Compounds in the Surface of Mars, J. Geophys. Res., 82, 28(1977), pp.4641-4658.

4) Klein, H. P.: The Viking Biological Investigation: General Aspects, J. Geophys. Res., 82, 28(1977), pp.4677-4680.

5) McKay, D. S., Gibson, E. K., Jr., Thomas-Keprta, K. L., Vali, H., Romanek, C. S., Clemett, S. J., Chillier, X. D. F., Maechling, C. R. and Zare R. N.: Search for Past Life on Mars: Possible Relic Biogenic Activity in Martian Meteorite ALH84001, Science, 273, 5277(1996), pp.924-930.

6) Glavin, D. P., Schubert, M., Botta, O., Kminek, G. and Bada, J. L.: Detecting Pyrolysis Products from Bacteria on Mars, Earth Planet. Scie. Lett., 185, 1-2 (2001), pp.1-5.

7) Benner, S. A., Devine, K. G., Matveeva, L. N. and Powell, D. H.: The Missing Organic Molecules on Mars, Proc. Natl. Acad. Sci. USA, 97, 6 (2000), 2425-2430.

8) Dartnell, L. R., Desorgher, L., Ward, J. M. and Coates, A. J.: Martian Sub-surface Ionising Radiation: Biosignatures and Geology, Biogeosciences, 4, 4 (2007), pp.545-558.

9) Kminek, G. and Bada, J. L.: The Effect of Ionizing Radiation on the Preservation of Amino Acids on Mars, Earth and Planetary Science Letters, 245, 1-2 (2006), pp.1-5

10) Malin, M. C. and Carr, M. H.: Groundwater Formation of Martian Valleys, Nature, 397, 6720 (1999), pp.589-591.

11) Malin, M. C. and Edgett, K. S.: Evidence for Persistent Flow and Aqueous Sedimentation on Early Mars, Science, 302, 5652 (2003), pp.1931-1934.

12) Masson, P., Carr, M. H., Costard, F., Greeley, R., Hauber, E. and Jaumann, R.: Geomorphologic Evidence for Liquid Water, Space Sci. Rev., 96, 1 (2001), pp.333-364.

13) Feldman, W. C., Boynton, W. V., Tokar, R. L., Prettyman, T. H., et al.: Global Distribution of Neutrons from Mars: Results from Mars Odyssey, Science, 297, 5578 (2002), pp.75-78.

14) Gendrin, A., Mangold, N., Bibring, J. P., Langevin, Y., Gondet, B., Poulet, F., Bonello, G., Quantin, C., Mustard, J., Arvidson, R. and LeMouelic, S.: Sulfates in Martian Layered Terrains: the OMEGA/Mars Express View, Science, 307, 5715(2005), pp.1587-1591.

15) Poulet, F., Bibring, J. P., Mustard, J. F., Gendrin, A., Mangold, et al.: Phyllosilicates on Mars and implications for early martian climate, Nature, 438, 7068 (2005), pp.623-627.

16) Squyres, S. W., Arvidson, R. E., Bell, J. F., 3rd, Bruckner, J., et al.: The Opportunity Rover's Athena Science Investigation at 
Meridiani Planum, Mars. Science, 306, 5702(2004), pp.1698-1703.

17) Squyres, S. W. and Knoll, A. H.: Sedimentary rocks at Meridiani Planum: Origin, Diagenesis, and Implications for Life on Mars, Earth Planet. Sci. Lett., 240, 1 (2005), pp.1-10.

18) Smith, P. H., Tamppari, L. K., Arvidson, R. E., Bass, D., Blaney, et al.: $\mathrm{H}_{2} \mathrm{O}$ at the Phoenix landing site. Science, 325, 5936 (2009), pp.58-61.

19) Formisano, V., Atreya, S., Encrenaz, T., Ignatiev, N. and Giuranna, M.: Detection of Methane in the Atmosphere of Mars, Science, 306, 5702 (2004), pp.1758-1761.

20) Geminale, A., Formisano, V. and Giuranna, M.: Methane in Martian Atmosphere: Average Spatial, Diurnal, and Seasonal Behaviour, Planet. Space Sci., 56 ,9 (2008), pp.1194-1203.

21) Krasnopolsky, V. A., Maillard, J. P. and Owen, T. C.: Detection of Methane in the Martian Atmosphere: Evidence for Life? Icarus, 172, 2 (2004), pp.537-547.

22) Mumma, M. J., Villanueva, G. L., Novak, R. E., Hewagama, T., Bonev, B. P., Disanti, M. A., Mandell, A. M. and Smith, M. D. Strong Release of Methane on Mars in Northern Summer 2003, Science, 323, 5917 (2009), pp.1041-1045.

23) Krasnopolsky, V. A.: Some Problems Related to the Origin of Methane on Mars, Icarus, 180, 2 (2006), pp.359-367.

24) Atreya, S. K., Mahaffy, P. R. and Wong, A.S.: Methane and Related Trace Species on Mars: Origin, Loss, Implications for Life, and Habitability, Planet. Space Sci., 55, 3 (2007), pp.358-369.

25) Lefevre, F. and Forget, F.: Observed Variations of Methane on Mars Unexplained by Known Atmospheric Chemistry and Physics, Nature, 460, 7256 (2009), pp.720-723.

26) Wbster, C.R. et al: Science Express, 2014.

27) Smith, M. D., M. Allen, D. Banfield, J. R. Barnes, R. T. Clancy, P. James, J. Kasting, P. Wennberg, D. Winterhalter, M. Wolff and R. Zurek. (2009) MARS TRACE GAS MISSION: Scientific Goals and Measurement Objectives. A White Paper submitted to the NRC Planet. Sci. Decadal Survey Panel September 15, 2009.

28) Ming, D. W. et al (2014) Science 343

29) Parnell, J., Cullen, D., Sims, M. R., Bowden, S., Cockell, S., Court, R., Ehrenfreund, P., Gaubert, F., Grant, W., Parro, V., Rohmer, M., Stephton, M., Stan-Lotter, H., Steele, A., Toporski, J. and Vago, J.: Searching for Life on Mars: Selection of Molecular Targets for ESA's Aurora ExoMars Mission, Astrobiol., 7, 4 (2007), pp. 478-604.

30) Yamagishi A., Yokobori, S., Yoshimura, Y., Yamashita, M., Hashimoto, H., Kubota, T., Yano, H., Haruyama, J., Tabata, M., Kobayashi, K., Honda, H., Utsumi, Y., Saiki, T., Itoh, T., Miyakawa, A., Hamase, K., Naganuma, T., Mita, H., Tonokura, K., Sasaki, S., and Miyamoto, H., Japan Astrobiology Mars Project (JAMP): Search for Microbes on the Mars Surface with Special Interest in Methane-Oxidizing Bacteria, Biol. Sci. Space 24(2010), pp.67-82

31) Rothschild, L. J. and Mancinelli R.L.: Life in Extreme Environments, Nature, 409(2001), pp.1092-1101.

32) Marion, G.M., Fritsen, C.H., Eicken, H. and Payne M.C.: The Search for Life on Europa: Limiting Environmental Factors, Potential Habitats, an Earth Analogues, Astrobiology, 3(2003), pp.785-811.

33) Jönsson, K.I., Rabbow, E., Schill, R. O., Harms-Ringdahl, M. and Rettberg P.: Tardigrades Survive Exposure to Space in Low Earth Orbit, Curr. Biol., 18(2008), R729-R731.

34) Junge, K., Eicken, H. and Deming, J.W.: Bacterial Activity at -2 to $-20^{\circ} \mathrm{C}$ in Arctic Wintertime Sea ice, Appl. Environ. Microbiol., 70(2004), pp.550-557.

35) Takai, K., Nakamura, K., Toki, T., Tsunogai, U., Miyazaki, M., Miyazaki, J., Hirayama, H., Nakagawa, S., Nunoura, T. and Horikoshi, K.: Cell Proliferation at $122^{\circ} \mathrm{C}$ and Isotopically Heavy $\mathrm{CH} 4$ Production by a Hyperthermophilic Methanogen under High-pressure Cultivation, Proc. Natl. Acad. Sci. USA, 105(2008), pp.10949-10954.

36) Sharma, A., Scott, J. H., Cody, G. D., Fogel, M. L., Hazen, R. M.,
Hemley, R. J. and Huntress, W. T.: Microbial Activity at Gigapascal Pressures, Science, 295(2002), pp.1514-1516.

37) Nicholson et al.: Proc. Natl. Acad. Sci.USA, 110(2013), pp.666-671.

38) Naganuma, T., and Horikoshi, K.: Extremely Halotolerant Halomonas sp. Isolated from a Tar Ball and Its Cellular Fatty Acid Composition, J. Mar. Biotechnol., 1 (1993), pp.151-157.

39) Okamoto, T., Maruyama, A., Imura, S., Takeyama, H. and Naganuma, T.: Comparative Phylogenetic Analyses of Halomonas Variabilis and Related Organisms based on 16S rRNA, gyrB and ectBC Gene Sequences, Syst. Appl. Microbiol., 27(2004), pp.323-333.

40) Horikawa, D. D., Sakashita, T., Katagiri, C., Watanabe, M., Kikawada, T., Nakahara, Y., Hamada, N., Wada, S., Funayama, T., Higashi, S., Kobayashi, Y., Okuda, T. and Kuwabara, M.: Radiation Tolerance in the Tardigrade Milnesium Tardigradum, Int. J. Rad. Biol., 82(2006), pp.843-848.

41) Watanabe, M., Sakashita, T., Fujita, A., Kikawada, T., Horikawa, D. D., Nakahara, Y., Wada, S., Funayama, T., Hamada, N., Kobayashi, Y. and Okuda, T.: Biological Effects of Anhydrobiosis in an African Chironomid, Polypedilum Vanderplanki on Radiation Tolerance, Int. J. Radiat. Biol., 82(2006), pp.587-592.

42) Watanabe, M., Sakashita, T., Fujita, A., Kikawada, T., Nakahara, Y., Hamada, N., Horikawa, D. D., Wada, S., Funayama, T., Kobayashi, Y. and Okuda, T.: Estimation of Radiation Tolerance to High LET Heavy Ions in an Anhydrobiotic Insect, Polypedilum Vanderplanki, Int. J. Radiat. Biol., 82(2007), pp.835-842.

43) Mashino, Y., Nakai, R., Nakamura, T. K., Yukimura, K., Shibuya, E., Migiyama, E., Kuroda, A., Takahashi, H., Naganuma, T., Imura, S., Iwatsuki, T., Kaneko, T., Kobayashi, K., Kobayashi, K., Sato, H., Saigusa, M., Shimada, K., Shirakabe, Y., Takano, Y., Takayama, K., Tawara, H., Hashimoto, H., Morita, Y., Yasuda, H. and Yamashita, M.: Microbial Survivability against High Dose X-ray and High Energy Fe ion, Space Utiliz. Res., 26(2010), pp.143-146.

44) Battista, J. R.: Against All Odds: the Survival Strategies of Deinococcus Radiodurans, Annu Rev Microbiol., 51(1997), pp.203-24.

45) Yasuda, H., Badhwar, G. D., Komiyama, T. and Fujitaka, K.: Effective Dose Equivalent on the Ninth Shuttle-Mir Mission (STS-91), Radiat. Res., 154(2000), pp.705-713.

46) Takahashi, A., and Ohnishi, T.: The Significance of the Study about the Biological Effects of Solar Ultraviolet Radiation using the Exposed Facility on the International Space Station, Biol. Sci. Space, 18(2004), pp.255-260.

47) Boynton, W. V., Ming, D. W., Kounaves, S. P., Young, S. M. M., Arvidson, R. E., Hecht, M. H., Hoffman, J., Niles, P. B., Hamara, D. K., Quinn, R. C., Smith, P. H., Sutter, B., Catling, D. C. and Morris, R. V.: Evidence for Calcium Carbonate at the Mars Phoenix Landing Site, Science, 325(2009), pp.61-64.

48) Hecht, M. H., Kounaves, S. P., Quinn, R. C., West, S. J., Young, S. M. M., Ming, D. W., Catling, D. C., Clark, B. C., Boynton, W. V., Hoffman, J., DeFlores, L. P., Gospodinova, K., Kapit, J., Smith, P. H.: Detection of Perchlorate and the Soluble Chemistry of Martian Soil at the Phoenix Lander Site, Science, 325(2009), pp.64-67.

49) Schleper, C., Piihler, G., Kuhlmorgen, B. and Zillig, W.: Life at ExtremelyLlow pH, Nature, 375(1995), pp.741-742.

50) Schleper, C., Puehler G., Holz, I., Gambacorta, A., Janekovic, D., Santarius, U., Klenk, H. P. and Zillig, W.: Picrophilus gen. nov., fam. nov.: a Novel Aerobic, Heterotrophic, Thermoacidophilic Genus and Family Comprising Archaea Capable of Growth around pH 0, J. Bacteriol., 177(1995), pp.7050-7059.

51) Takai, K., Moser, D. P., Onstott, T. C., Spoelstra, N., Pfiffner, S. M., Dohnalkova, A. and Fredrickson, J. K.: Alkaliphilus transvaalensis gen. nov., sp. nov., an Extremely Alkaliphilic Bacterium Isolated from a Deep South African Gold Mine, Int. J. Syst. Evol. Microbiol., 51(2001), pp.1245-56.

52) Coates, J. D., Michaelidou, U., Bruce, R. A., O'Connor, S. M., 
Crespi, J. A. and Achenbach, L. A.: Ubiquity and Diversity of Dissimilatory (Per)chlorate-reducing Bacteria, Appl. Environ. Mircobiol., 65(1999), pp.5234-41.

53) Coates, J. D., and Achenbach, L. A.: Microbial Perchlorate Reduction: Rocket-fuelled Metabolism, Nat. Rev. Microbiol., 2(2004), pp.569-580.

54) Atreya, S.K., Wong, A., Renno, N. O., Farrell, W. M., Delory, G. T., Sentman, D. D., Cummer, S. A., Marshall, J. R., Rafkin, S. C. R. and Catling, D.C.: Oxidant Enhancement in Martian Dust Devils and Storms: Implications for Life and Habitability, Astrobiology, 6(2006), pp.439-450.

55) Mancinelli, R. L.: Peroxides and the Survivability of Microorganisms on the Surface of Mars, Adv. Space Res., 9, 6 (1989), pp.191-195.

56) Yen, A. S., Kim, S. S., Hecht, M. H., Frant, M. S., Murray, B.: Evidence that the Reactivity of the Martian Soil is due to Superoxide Ions, Science, 289(2000), pp.1909-1912.

57) Haugland, R. P.: Handbook of Fluorescent Probes and Research Chemicals, 6th ed., Molecular Probes Inc. Eugend OR USA, 1996.

58) Herman, B.: Fluorescence Microscopy, 2nd ed., Bios Scientific Publishers, Oxford UK, 1998.

59) Weinstein, S., Pane, D., Ernst, LA, Warren-Rhodes, K., Dohm, JM, et al.: Application of Pulsed-excitation Fluorescence Imager for Daylight Detection of Sparse life in Tests in the Atacama Desert, J. Geophys. Res., 113(2008), G01S90.

60) Kawasaki, Y.: Direct Detection of Martian Microorganisms based on Fluorescence Microscopy, Adv. Space Res., 23, 2(1999), pp.309-317.

61) Kepner, R. L., Jr. and Pratt, J. R.: Use of Fluorochromes for Direct Enumeration of Total Bacteria in Environmental Samples: Past and Rresent, Microbiol. Rev., 58, 4 (1994), pp.603-15.

62) Klauth, P., Wilhelm, R., Klumpp, E., Poschen, L. and Groeneweg, J.: Enumeration of Soil Bacteria with the Green Fluorescent Nucleic Acid Dye Sytox Green in the Presence of Soil Particles, J. Microbiol. Methods, 59, 2(2004), pp.189-98.

63) Weinbauer, M. G., Beckmann, C. and Hofle, M. G.: Utility of Green Fluorescent Nucleic Acid Dyes and Aluminum Oxide Membrane Filters for Rapid Epifluorescence Enumeration of Soil and Sediment Bacteria, Appl. Environ. Microbiol., 64, 12(1998), pp.5000-5003.

64) Shibata, A., Goto, Y., Saito, H., Kikuchi, T., Toda, T. and Taguchi, S.: Comparison of SYBR Green I and SYBR Gold Stains for Enumerating Bacteria and Viruses by Epifluorescence Microscopy, Aquatic Microbial Ecology, 43, 3(2006), pp.223-231.

65) Nadeau, J. L., Perreault, N. N., Niederberger, T. D., Whyte, L. G., Sun, H. J. and Leon, R.,: Fluorescence Microscopy as a Tool for in situ Life Detection, Astrobiology, 8, 4(2008), pp.859-874.

66) Lundgren, B.: Fluorescein Diacetate as a Stain of Metabolically Active Bacteria in Soil, Oikos, 36(1981), pp.17-22

67) Porter, J., Diaper, J., Edwards, C. and Pickup, R.: Direct Measurements of Natural Planktonic Bacterial Community Viability by Flow Cytometry, Appl. Environ. Microbiol., 61, 7 (1995), pp.2783-2786.

68) Soderstrom, B. E.: Vital Staining of Fungi in Pure Cultures and in
Soil with Fluorescein Diacetate, Soil Biol. Biochem., 9(1977), pp.59-63.

69) Soderstrom, B. E.: Some Problems in Assessing the Fluorescein Diacetate-Active Fungal Biomass in the Soil, Soil Biol. Biochem., 11(1979), pp.147-148.

70) Tsuji, T., Kawasaki, Y., Takeshima, S., Sekiya, T. and Tanaka, S.: A New Fluorescence Staining Assay for Visualizing Living Microorganisms in Soil, Appl. Environ. Microbiol., 61, 9(1995), pp.3415-3421.

71) Ashida, N., Ishii, S., Hayano, S., Tago, K., Tsuji, T., Yoshimura, Y., Otsuka S. and Senoo, K.: Isolation of Functional Single Cells from Environments using a Micromanipulator: Application to Study Denitrifying Bacteria, Appl. Microbiol. Biotech., 85(4) (2009), pp.1211-1217.

72) Auty, M. A., Gardiner, G. E., McBrearty, S. J., O'Sullivan, E. O., Mulvihill, D. M. , Collins, J. K., Fitzgerald, G. F., Stanton, C. and Ross, R. P.: Direct In situ Viability Assessment of Bacteria in Probiotic Dairy Products using Viability Staining in Conjunction with Confocal Scanning Laser Microscopy, Appl Environ Microbiol, 67, 1(2001), pp.420-425.

73) Zubkov, M. V., Fuchs, B. M., Eilers, H., Burkill, P. H., Amann, R.: Determination of Total Protein Content of Bacterial Cells using SYPRO Staining and Flow Cytometry, Appl Environ Microbiol, 65(1999), pp.3251-3257.

74) Oze, C. and Sharma, M.: Have Olivine, Will Gas: Serpentinization and the Abiogenic Production of Methane on Mars, Geophys. Res. Lett., 32(2005), L10203.

75) McEwen, A.S., Ojha, L., Dundas, C.M., Mattson, S.S., Byrne, S., Wray, J.J., Cull, S.C., Murchie, S.L., Thomas, N. and Gulick, V.C.: Seasonal Flows on Warm Martian Slopes, Science, 333(2011), pp.740-743.

76) McEwen, A.S., Dundas, C.M., Mattson, S.S., Toigo, A.D., Ojha, L., Wray, J.J., Chojnacki, M., Byrne, S., Murchie, S.L. and Thomas, N.: Recurring Slope Iineae in Equatorial Regions of Mars, Nature Geoscience, 7(2014), pp.53-58.

77) Ojha, L., McEwen, A., Dundas, C., Byrne, S., Mattson, S., Wray, J., Masse, M. and Schaefer, E.: HiRISE Observations of Recurring Slope Lineae (RSL) during Southern Summer on Mars. Icarus, 231(2014), pp.365-376.

78) Summons, R. E., Brunner, A. E., Buch, A., Szopa, C., Archer, P. D., Franz, H. B., Atreya, S. K., Brinckerhoff, W. B., Cabane, M., Coll, P., Conrad, P. G., Des Marais, D. J., Dworkin, J. P., Fairén, A. G., François, P., Grotzinger, J. P., Kashyap, S. Kate, I. L. ten., Leshin, L. A., Malespin, C. A., Martin, M. G., Martin-Torres, F. J., McAdam, A. C., Ming, D. W., Navarro-González, R. Pavlov, A. A., Prats, B. D., Squyres, S. W., Steele, A., Stern, J. C., Sumner, D. Y., Sutter, B., and Zorzano, M-P.: Organic Molecules in the Sheepbed Mudstone, Gale Crater, Mars. J. Geophys. Res. Planets, 120, 3 (2015), pp.495-514. 